\title{
GEOLOGIC MAP OF THE MONTE CRISTO RANGE AREA, ESMERALDA AND MINERAL COUNTIES, NEVADA
}

\author{
By J.H. Stewart, P.C. Kelleher, and E.A. Zorich
}

\section{INTRODUCTION}

Ferguson and others (1953) first mapped the geology of the Monte Cristo Range in reconnaissance at a scale of $1: 125,000$, and this map, including slight additions, was used by Albers and Stewart (1972) on a 1:250,000scale map of Esmeralda County. Ferguson (1928) published a geologic map of the Gilbert district, and Ferguson and Muller (1949, fig. 10) published a map of part of the western Monte Cristo Range. More recently, Moore (1981) mapped and described an area in the southern part of the range, and Hambrick (1984) mapped an area in the southwestern part of the range. Phariss (1974) and Maldonado (1984) mapped parts of Lone Mountain in the southeastern part of the map area. Speed and Cogbill (1979) and Speed (1981, 1984) mapped the geology of areas in the western part of the map area and in areas to the west and northwest of the map area. Geologic maps adjacent to the map area are by Whitebread and Hardyman (1987) to the northeast, Bonham and Garside (1979) to the east, Robinson and others (1976) to the southwest, and Molinari $(1984 \mathrm{a}, \mathrm{b})$ to the north. The map and figures presented here incorporate information from Ferguson (1928), Ferguson and Muller (1949, fig. 10), Phariss (1974), Moore (1981), Hambrick (1984), Maldonado (1984), R.C. Speed (written commun., 1985), D.H. Whitebread (written commun., 1986), D.A. John (written commun., 1986), and our own mapping from 1982 to 1985 (fig. 1). Our mapping was part of the Tonopah $1^{\circ}$ by $2^{\circ}$ quadrangle project of the Conterminous United States Mineral Appraisal Program (John and others, 1991).

Albers and Stewart (1972) give a summary of the mineral deposits in the Monte Cristo Range and adjacent areas, and specific information on some aspects of these deposits is given by Ferguson (1928), Sandy (1965), Nash and others (1985), and Orris and Kleinhampl (1986). During the late 1980's and early 1990's, two open-pit gold-silver mines (McLean and Boss Mines) were active in the area (The Nevada Mineral Industry, 1987; Ehni, 1991).

\section{PRE-TERTIARY SEDIMENTARY AND VOLCANIC ROCKS}

Pre-Tertiary sedimentary and volcanic rocks are exposed in small- to moderate-size outcrops across the map area. They are divided into six distinctive lithologic and structural assemblages. The relations among assemblages are not always evident within the map area because outcrops are discontinuous, but relations generally are known from outcrops outside of the map area or from regional relations. The assemblag?s, from lower to higher structural levels, are (1) Cordilleran miogeoclinal strata, (2) Roberts Mountains allc chthon, (3) parautochthonous cover of the Roberts Mountains allochthon, (4) serpentinite melange, (5) Golconda allochthon, and (6) Gold Range terrane of Silberling (1991), which is equivalent to Sonomia of Speed' (1984).

Cordilleran miogeoclinal strata crop out on Lone Mountain in the southeastern part of the miv area. They consist of the Late Proterozoic and Lower Cambrian Reed Dolomite and the conformably(?) underlying Wyman Formation. These formations consist mainly of shallow-water shelf strata that are the oldest part of the Late Proterozoic and early to middle Paleozoic Cordilleran miogeocline in Nevada (Stewart, 1980). Younger strata of the miogeocline are not exposed in the map area, but elsewhere in Nevada the miogeocline contains strata as young as Devonian.

Siliceous and volcanic rocks of Cambrian to $\mathrm{De}$ vonian age (DEsv, $D \in g$ ), assigned here to the Roberts Mountains allochthon, are fairly widely exposed in the Monte Cristo Range and Candelaria Hills, but nowhere in the map area are they in contact with rocks of the Cordilleran miogeocline. Regionally, th ?y form a major allochthon that structurally overlies rocks of the Cordilleran miogeocline, although some uncertainty exists (see discussion by Stewart, 1980) about horw closely these rocks in the Monte Cristo Range and Candelaria Hills are related to rocks of the Roberts Mountains allochthon in northern Nevada, where the allochthon was first recognized. The rocks assigned to the Roberts Mountains allochthon in the Monte Cristo Range area consist mostly of moderately deep water to deep-water radiolarian chert, graptolitic shale, argillite, $s^{i}$ tstone, very fine grained sandstone, fine- to coarse-grained quartzite, and limestone. Volcanic rocks are present in the Candelaria Hills, and a major unit of greonstone breccia $(D \in g)$ is mapped separately on the scithwest side of the Monte Cristo Range. Based on regional relations, emplacement of the Roberts Mcuntains allochthon is considered to be Late Devonian or Early Mississippian in age (Stewart, 1980).

Parautochthonous cover rocks of the Rober's Mountains allochthon consist of thin units of Mississippian and Permian strata and thick units of Triassi- strata. The thin Mississippian carbonate rocks (Mc) appear to lie unconformably on siliceous and volcanic rocks 
of the Roberts Mountains allochthon in the Candelaria Hills (Speed, 1984), but, in the Monte Cristo Range, the contact with underlying silicious and volcanic rocks appears to be everywhere a low-angle fault (apparently a thrust). The thin Permian strata consist of conglomerate, calcarenite, and sandstone of the Diablo Formation (Pd). The Lower Triassic Candelaria Formation (Fc) conformably(?) overlies the Diablo Formation in the Candelaria Hills west of the map area and crops out in the map area only in the easternmost part of the Candelaria Hills. Where fully exposed in the Candelaria Hills west of the map area, the Candelaria Formation is more than $1 \mathrm{~km}$ thick and consists of shallow-water marl, mudstone, chert-grain sandstone, and limestone in its lower part and an overlying, coarsening-upward sequence of mudstone and volcaniclastic turbidite (Speed, 1977b; 1984). The Candelaria Formation is interpreted to represent deposition in a deepening basin during encroachment of a volcanic arc terrane (Speed, 1977b; 1984).

Serpentinite melange forms a narrow band of outcrops across the Candelaria Hills, mostly west of the map area. The only outcrops in the map area are present in the easternmost part of the Candelaria Hills. The melange in the map area consists of serpentinite and tectonically intercalated slate $\left(\mathrm{MzP}_{2} \mathrm{~s}\right)$, but elsewhere consists of blocks of limestone, bedded chert, diabase, foliated siliceous volcanic rocks, sedimentary breccia, vein quartz clasts, and quartzite in a serpentinite matrix (Speed, 1984). Blocks in the melange range in age from Mississippian to Early Triassic (Speed, 1984). In the Candelaria Hills, the melange lies in a thin thrust plate between the Candelaria Formation and the Golconda allochthon. Speed (1984) interprets the serpentinite melange as a tectonic assemblage that forms the base of the Golconda allochthon. According to Speed (1984) the origin of the serpentinite is problematical and could be diapiric or related to accretion of oceanic crust.

The Golconda allochthon is represented in the map area by outcrops of the Havallah sequence $(\mathrm{Ph})$ in the Coaldale and Gilbert $71 / 2$ ' quadrangles (fig. 2). In these quadrangles, dated rocks of the Havallah sequence are Pennsylvanian in age, but in the Candelaria Hills west of the map area the Havallah sequence ranges in age from Mississippian to Permian (Speed, 1984). The Havallah sequence consists mostly of siltstone, phyllite, and minor chert-grain sandstone in the map area, but in the Candelaria Hills it is a more diverse assemblage of biogenic chert, hemipelagic chert and pelite, terrigenous and calcareous turbidite, and mafic volcanic rocks that are interpreted as having a deepwater origin (Speed, 1984). A unit of sedimentary breccia $\left(\mathrm{MzP}_{2} \mathrm{~s}\right)$ in the Candelaria Hills is of unknown affinity, but may also be part of the Golconda allochthon. According to Speed (1984), the Golconda allochthon was emplaced during the Sonoma orogeny. He dates this orogeny and the emplacement of the Golconda allochthon as Early Triassic in age based on the interpreted encroachment of a volcanic arc and related tectonic activity during deposition of the Lower Triassic Candelaria Formation.
The structurally highest Paleozoic rocks in the map area are assigned to the Permian Mina Formation of Speed (1977a), part of the Gold Range terrane of Silberling (1991), which is also called Sonomia by Speed (1984). These rocks are present in isolated outcrops in the northern part of the Monte Cristo Range and may have been displaced into this position along the proposed Mesozoic right-lateral Excelsior Fault zone described below. The Mina Formation (Pm) consists of chert, volcaniclastic arenite, and argillite, probably deposited near a volcanic arc (Speed, 1977b; 1984) and structurally emplaced during the Early Triassic Sonoma orogeny (Speed, 1984).

\section{GRANITIC ROCKS}

Four granitic bodies crop out in the map area (John, 1987; John and Robinson, 1989). Two of these are considered to be earliest Jurassic in age: (1) the granitic rocks of the Gilbert district (Jgg) consisting of porphyritic biotite-hornblende granodiorite or granite and dated on the basis of a K-Ar alteration age (no. 14, table 1) and (2) the Crow Springs pluton (Jcs) consisting of coarsely porphyritic biotite-hornblende granodiorite or quartz monzodiorite and dated on the basis of a hornblende $\mathrm{K}-\mathrm{Ar}$ age (no. 15, table 1) and a Rb-Sr whole-rock age (John and Robinson, 1989). These two granitic bodies crop out, respectively, in the Gilbert and Crow Springs $71 / 2$ ' quadrangles. The Lone Mountain pluton in the southeastern part of the quadrangle is the largest pluton in the map area. This body is Late Cretaceous in age based on muscovite and biotite $\mathrm{K}-\mathrm{Ar}$ ages (Silberman and others, 1975; Bonham and Garside, 1979, table 4) and a Rb-Sr wholerock age (John and Robinson, 1989), all from east of the map area. The Lone Mountain pluton consists of sparsely porphyritic, foliated biotite granite and garnetmuscovite-biotite granite. Finally, a small area of porphyritic granitic rock that has a Late Cretaceous $\mathrm{K}-\mathrm{Ar}$ muscovite alteration age (no.13, table 1) crops out in the easternmost part of the Candelaria Hills in the Rock Hill $71 / 2^{\prime}$ quadrangle.

\section{TERTIARY VOLCANIC AND SEDIMEN- TARY ROCKS}

Tertiary volcanic and sedimentary rocks form most of the bedrock outcrops in the Monte Cristo Range. These rocks can be divided into six major sequences or units (fig. 3): (1) Oligocene and Miocene silicic ashflow tuffs ( 23 to $29 \mathrm{Ma}$ ); (2) andesites, dacite, tuff, and associated sedimentary and intrusive rocks of the Blair Junction sequence (15 to $22 \mathrm{Ma}$ ); (3) the sedimentary rocks of McLeans; (4) the Gilbert Andesite (15 Ma); (5) the Esmeralda Formation (11 to $13 \mathrm{Ma}$ ); and (6) rhyolite and basalt $(7 \mathrm{Ma}$ ).

Oligocene or Miocene silicic ash-flow tuffs (23 to $29 \mathrm{Ma}$ ) are present in scattered outcrops throughout the Monte Cristo Range area. In most of the range, these tuffs are assigned to the tuff of Castle Peak (Tcp). These rocks were originally referred to as the Castle Peak tuff unit by Moore (1981) for exposures at Castle 
Peak (Devils Gate $71 / 2$ ' quadrangle) in the southern part of the Monte Cristo Range. This unit name is used here, in a slightly modified form, to describe a sequence of rhyolitic tuffs. Mapping or correlation of individual ash flows within the tuff of Castle Peak is difficult because of argillic alteration, discontinuous outcrops, and structural complexities, and we did not attempt to subdivide the unit in our mapping. Moore (1981) divided his Castle Peak tuff unit into three subunits, and Hambrick (1984) divided what she called the "Castle Peak volcanic sequence" into four subunits. They both include in their Castle Peak units not only rocks that we map as our tuff of Castle Peak, but other rocks that we map as the tuff unit of the Blair Junction sequence. As we use the name here, the tuff of Castle Peak is a composite unit of several petrographically distinct, but here undivided, individual ash-flow tuffs.

Other Oligocene or Miocene silicic ash-flow tuffs are recognized elsewhere in the Monte Cristo Range area. In the northwestern part of the range, two ashflow units are recognized: (1) a lower unnamed tuff $(T t)$ and (2) the tuff of Summit Spring (Tss). The tuff of Summit Spring is named for Summit Spring located north of the map area in the Eddyville $71 / 2^{\prime}$ quadrangle, where the unit crops out fairly extensively. In the southwestern part of the map area, small outcrops of tuff are assigned to a sequence of tuffs that is widely exposed to the south in the adjacent Rhyolite Ridge quadrangle (Robinson and others, 1976; Robinson and Stewart, 1984). In the northeastern part of the map area, other tuffs are assigned to several informally named units that are recognized more extensively to the northeast of the map area (Whitebread and Hardyman, 1987). Each of the four areas of Oligocene and Miocene silicic ash-flow tuffs (central, northwestern, southwestern, and northeastern parts of the Monte Cristo Range) appear to contain different sequences of tuffs that are not correlative with each other, although more work is needed to confirm this.

The name "Blair Junction sequence" is used here to identify a sequence of andesite and dacite flows and shallow intrusions. The middle part of the sequence contains a tuff unit. Hambrick (1984) used the name "Blair Junction volcanic sequence" for some of the same rocks that we include as part of the Blair Junction sequence here, but, in addition, Hambrick used the name "Coaldale volcanic sequence" for rocks that we also include in our Blair Junction sequence. The sequence is not the same as the Blair Junction sequence of Moore (1981), who used the name to describe part of the Esmeralda Formation in the Blair Junction 7 $1 / 2$ ' quadrangle. The Blair Junction sequence used here overlies the Oligocene or Miocene silicic ash-flow tuffs. It includes three major units: the upper and lower units are composed of andesite, dacite, and associated sedimentary and intrusive rocks, and the (medial) tuff unit is composed of lithic- and pumice-rich, vitric, nonwelded, pyroclastic tuff. The lower unit is 22.2 $\mathrm{Ma}$, the tuff unit is $16.6 \mathrm{Ma}$, and the upper unit is 15.7 Ma in age (nos. 6, 7, and 11 , table 1 ; fig. 3 ). This dating indicates that the Blair Junction sequence was deposited over a 6.5-m.y. time range. This age span and the petrographic variety of the rocks in the Blair Junction sequence (see Description of Mao Units) suggest that the sequence probably contains rocks derived from diverse volcanic sources.

Silicic shallow intrusions and flow domes ranging in age from about 18 to $20 \mathrm{Ma}$ occur in a telt that extends south-southeastward across the northern part of the Monte Cristo Range and in isolated outcrops elsewhere in the map area: The age of these rocks is younger than dated rocks from the lower unit of the Blair Junction sequence and older than the dated tuff unit of the sequence. These silicic rocks consist of rhyolite (Tor), porphyritic rhyolite (Tpr), porphyritic dacite (Td), porphyritic dacite tuff breccia (Tdt), rhyolitic to dacitic(?) tuff breccia (Trb), and dacite (Tda).

The sedimentary rocks of McLeans, named for McLeans in the Devils Gate $71 / 2^{\prime}$ quadrangle, are generally less than $30 \mathrm{~m}$ thick but extend throughout much of the Monte Cristo Range. The unit, which consists of siltstone, shale, very fine grained sandstone, and abundant diatomite, forms a useful marker that separates the Blair Junction sequence below f`om the Gilbert Andesite above.

The Gilbert Andesite is a widespread and locally thick unit in the Monte Cristo Range. It forms massive resistant outcrops capping many of the highost hills in the Monte Cristo Range. As originally described by Ferguson and others (1953), the Gilbert A ndesite constitutes most of the andesitic rocks in the. Monte Cristo Range (see discussion by Moore, 1981). We here stratigraphically restrict the unit to tr. most conspicuous and widespread andesite in the Monte Cristo Range. As so revised, the Gilbert Andesite dies not include andesites that we have reassigned to the Blair Junction sequence (see above) and were previously included in the Gilbert Andesite by Ferguson and others (1953). The Gilbert Andesite consists of anderite and trachyandesite lava flows and volcanic breccia (lahars and flow breccia) that commonly contain greer-weathering clinopyroxene phenocrysts. It has been dated isotopically as about $15 \mathrm{Ma}$ in age (nos. 4 and 5 , table 1).

In the map area, the Esmeralda Formation is widely exposed south of the Monte Cristo Range, where, locally, it has been divided into 11 lithic units. In the region south of the map area, the Esmeralda Formation is also widespread, and isotopic ages on tuffs in the formation range from about 11 to $13 \mathrm{Ma}$ (Stewart and Diamond, 1990). The Esmeralda Formation in and near the southwestern part of the map area is about $1,300 \mathrm{~m}$ thick and consists of siltstone and porcelaneous siltstone, sandstone, clast- and matrix-supported conglomerate, carbonaceous shale, lignite, coars? volcanic breccia, and tuff (Stewart, 1989). The north?rnmost extent of the Esmeralda Formation in the map area is uncertain. It may have originally extended completely across the range and subsequently was eroded, or the southern part of the range may have boen the northern margin of its depositional basin. The undivided sedimentary rocks unit (Tsu) in the northern 
part of the range lithologically resembles the Esmeralda Formation and is tentatively considered to include rocks temporally equivalent to the sedimentary rocks of McLeans, as well as the Esmeralda Formation. In this interpretation, the normally intervening Gilbert Andesite must pinch out northward in an area of Quaternary cover south of outcrops of the undivided sedimentary rocks unit.

A belt of rhyolite flow domes $(T r)$ and associated rhyolite breccia (Tsr) and sedimentary rocks (Ts) extends north-northeastward along the east side of the Monte Cristo Range. A K-Ar date (Silberman and others, 1975) on black obsidian (apache tears) from one of the lava domes is $7.2 \mathrm{Ma}$, and most of the domes are considered to be similar in age based on their similar lithologies and close spatial distribution. Pyroclastic and sedimentary deposits derived from these lava domes constitute units Ts and Tsr.

Basalt flows (Tb) and intercalated sandstone and conglomerate (Tbs) are extensively exposed in the northern part of the map area. The southern outcrops of these units form a conspicuous south-southwest-trending belt of nearly continuous exposures that approximately follow the orientation of, but is directly south of, the belt of silicic intrusive rocks (Tor, Tpr, Td, Tdt, Trb, Tda). A K-Ar date of $7.2 \mathrm{Ma}$ (see no.1, table 1, for exact location) was obtained from a basalt flow in unit Tb in the northeastern part of the map area. This dated basalt is relatively unfaulted, yet lies above sections of basalt flows and intercalated sedimentary rocks (also included within unit Tb) that are greatly different stratigraphically on either side of a northwest-trending fault near the locality of the dated basalt flow. These relations indicate that the fault was active after the deposition of the sections of basalt flows and sedimentary rocks, but before the deposition of the capping 7.2Ma basalt flow.

\section{MESOZOIC AND CENOZOIC EXCELSIOR FAULT ZONE AND RELATED LINEA- MENTS}

A major east- to east-southeast-trending fault zone, the Excelsior Fault zone, has been proposed by Stewart (1985) to cut across the northern part of the Monte Cristo Range (fig. 4). The presence of this fault zone is suggested by a poorly defined to well-defined zone of faults that cuts Cenozoic and older rocks extending from west of the Monte Cristo Range into the northwestern part of the map area. The fault zone marks an apparent disruption in the distribution of Paleozoic and lower Mesozoic rocks that is interpreted by Stewart (1985) as due to 45 to $55 \mathrm{~km}$ of rightlateral displacement. Major movement on the Excelsior Fault zone is considered to be late Mesozoic in age because in areas outside of the map area the Lower and Middle Jurassic (and perhaps younger) Dunlap Formation appears to be offset by the fault zone, whereas mid-Cretaceous plutons are not. Local reactivation of the faults in Cenozoic time accounts for the offset of Cenozoic rocks (Stewart, 1985).
In the Monte Cristo Range, the Excelsior Fault zone separates markedly different assemblages of Paleozoic rocks. South of the fault zone, Paleozoic rocks consist of Upper Cambrian and Devonian siliceous and volcanic rocks, Mississippian carbonate rocks, and Pennsylvanian siltstone and phyllite of the Havallah sequence. North of the fault zone, outcrops of Paleoz jic rocks consist only of chert, volcaniclastic arenite, ant argillite of the Permian Mina Formation of Speed (1977a). The presence of the fault zone in the northwesternmost part of the range is suggested by several poorly defined zones of largely concealed east- to east-southeast-trending faults. In the main part of the Monte Cristo Range, faults parallel to the inferred Excelsior fault zone are sparse or absent. The distribution of Cenoznic rocks, however, suggests a major structural featuri? parallel or subparallel to the inferred Excelsior Fault zone. The most obvious pattern that suggests a link with the Excelsior Fault zone is the distribution of basalt flows (Tb) that trend southeast across the northern part of the Monte Cristo Range at a slight angle to, and diverging to the south from, the inferred position of the Excelsior Fault zone (fig. 4). Rhyolitic rocks (Tor, Tpr, Td, Trb, Tda, Tr) are also present in a broad zon? parallel to the Excelsior Fault zone (Stewart, 1985. In addition, the Gilbert Andesite ( $\mathrm{Tg}$ ) appears to terminate northward approximately at the Excelsior Fa ult zone, and Miocene sedimentary rocks (Tsu) thicken northward across the inferred position of the fault zone.

\section{POSSIBLE TERTIARY CALDERA STRUC- TURES}

The arcuate shape of the Monte Cristo Range is suggestive of a possible volcanic structure, perhaps a caldera, but field evidence is inconclusive. The presence of large exotic blocks, some tens of meters across, of pre-Tertiary rocks or of Tertiary tuffs embedded within the upper Oligocene or lower Miocene tuff of Castle Peak (fig. 4) is indicative of either pyroclastic or landslide blocks derived from nearby sources, concei"ably the wall of a cauldron. On the other hand, the distribution of rhyolitic flows and intrusive rocks (Tor, Tpr, Td, Tdt, Trb, Tda) that are only a few million years younger than the tuff of Castle Peak do not define an arcuate or circular pattern as might be expected if they were intruded along the ring fracture of a caldera. Furthermore, the tuff of Castle Peak is composed of at least four, and perhaps several more, petrographically distinct and relatively thin ash-flows that appear to be outflow sheets rather than intracaldera fill. Perhans further study of the distribution of the large blocks and details of the internal stratigraphy of the tuff of Castle Peak will reveal the presence of a caldera structure of late Oligocene to early Miocene age in the Morte Cristo Range, but present information is inconclusive.

A younger (early to middle Miocene) caldera structure is also possible in the Monte Cristo Range. Tr? arcuate shape of the range is defined primarily by the distribution of the 15-Ma Gilbert Andesite. Perhaps the locally thick 16.6-Ma tuff unit of the Blair Junction 
sequence (fig. 2) that underlies the Gilbert Andesite was derived from caldera-forming eruptions within the Monte Cristo Range, and the Gilbert Andesite was erupted along ring fractures of this caldera. The distribution of the Gilbert Andesite suggests three arcuate trends (fig. 4), indicating that a volcanic center, if it existed, may have consisted of several overlapping calderas. Still, the evidence for this younger caldera or calderas is inconclusive.

\section{LATE CENOZOIC UPLIFT}

The higher elevation of the Monte Cristo Range relative to surrounding valleys appears to be due primarily to late Cenozoic domal uplift rather than to downdropping of surrounding blocks along basin-and-range normal faults. A structure contour map of the base of the Gilbert Andesite (fig. 5) shows considerable relief, particulary in the eastern part of the range where a domal structure has over $2,300 \mathrm{ft}(700 \mathrm{~m})$ of relief. This relief is considered to be due to uplift that is related to the intrusion of igneous rocks, rather than to original topographic irregularities of the surface on which the the Gilbert Andesite was extruded. The Gilbert rests on a thin, widespread sedimentary unit (sedimentary rocks of McLeans) that represents lake deposits and presumably had little original topographic relief.

The conspicuous dome in the eastern part of the range most likely resulted from the intrusion of $7-\mathrm{Ma}$ rhyolitic rocks that crop out along the east flank of,

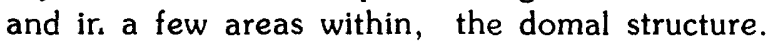

\section{REFERENCES CITED}

Albers, J.P., and Stewart, J.H., 1972, Geology and mineral deposits of Esmeralda County, Nevada: Nevada Bureau of Mines and Geology Bulletin 78, $80 \mathrm{p}$.

Bonham, H.F., Jr., and Garside, L.J., 1979, Geology of the Tonopah, Lone Mountain, Klondike, and Northern Mud Lake quadrangles, Nevada: Nevada Bureau of Mines and Geology Bulletin 92, $142 \mathrm{p}$.

Dalrymple, G.B., 1979, Critical tables for conversion of K-Ar ages from old to new constants: Geology, v. 7, p. $558-560$.

Ehni, W. J. , 1991, The use of vertical electrical sounding in mineral exploration, in Raines, G.L., Lisle, R.E., Schafer, R.W., and Wilkinson, W.H., eds., Geology and ore deposits of the Great Basin: Reno, Nevada, Geological Society of Nevada, p. 12211230.

Ekren, E.B., Byers, F.M., Jr., Hardyman, R.F., Marvin, R.F., and Silberman, M.L., 1980, Stratigraphy, preliminary petrology, and some structural features of Tertiary volcanic rocks in the Gabbs Valley and Gillis Ranges, Mineral County, Nevada: U.S. Geological Survey Bulletin 1464, $54 \mathrm{p}$.

Epstein, A.G., Epstein, J.B., and Harris, L.D., 1977, Conodont color alteration - an index to organic meta- morphism: U.S. Geological Survey Professional Paper 995, 27 p.

Evernden, J.F., and James, G.T., 1964, Pot'ssiumargon dates and the Tertiary floras of North A merica: American Journal of Science, v. 264, p. 94:5-974.

Ferguson, H.G., 1928, The Gilbert district, Nevad": U.S. Geological Survey Bulletin 795, p. 125-145.

Ferguson, H.G., and Muller, S.W., 1949, Structural geology of the Hawthorne and Tonopah quadrangles, Nevada: U.S. Geological Survey Professionel Paper 216, $55 \mathrm{p}$.

Ferguson, H.G., Muller, S.W., and Cathcart, S.H., 1953, Geology of the Coaldale quadrangle, Nevada: U.S. Geological Survey Geologic Quadrangle Map GQ23, scale $1: 125,000$.

Hambrick, D.A., 1984, Geochemistry and structure of Tertiary volcanic rocks in the southern Mont? Cristo Range, Nevada: Tucson, Ariz., University of Arizona, M.S. thesis, $140 \mathrm{p}$.

John, D.A., 19.87, Map showing the distribution and characteristics of plutonic rocks in the Tonopah $1^{\circ}$ by $2^{\circ}$ quadrangle, central Nevada: U.S. Geological Survey Miscellaneous Field Studies Map MF-1877$\mathrm{J}$, scale 1:250,000.

John, D.A., Nash, J.T.,Plouff, Donald, and Whitebread, D.H., 1991, The Conterminous United States Mineral Appraisal Program: Background information to accompany folio of geologic, geochemical, geophysical, and mineral resources maps of the Tonopah $1^{\circ}$ by $2^{\circ}$ quadrangle, Nevada: U.S. Geological Survey Circular 1070, 16 p.

John, D.A., and Robinson, A.C., 1989, Rb-Sr wholerock isotopic ages of granitic plutons in the western part of the Tonopah $1^{\circ}$ by $2^{\circ}$ quadrangle, Nevada: Isochron/West, no. 53, p. 20-27.

Maldonado, Florian, 1984, Bedrock geologic map of the Lone Mountain pluton area, Esmeralda County, Nevada: U.S. Geological Survey Miscellaneous Investigation Series Map I-1533, scale 1:24,000.

McKee, E.H., and John, D.A., 1987, Map showing the location of samples used and K-Ar dating of Cenozoic rocks and minerals in the Tonopah $1^{\circ} \times 2^{\circ}$ quadrangle, central Nevada: U.S. Geological Survey Miscellaneous Field Studies Map MF-1877-I, scale $1: 250,000$.

Molinari, M.P., 1984a, Late Cenozoic geoloxy and tectonics of the Stewart and Monte Cristo Valleys, west-central Nevada: Reno, Nev., University of Nevada, M.S. thesis.

1984b, Late Cenozoic structural geology' of the Stewart and Monte Cristo Valleys, Walker J ane of west central Nevada, in Lintz, Joseph Jr., ed., W/estern Geological Excursions: Geological Society of America, Annual Meeting, Reno, Nevada, v. 4, p. 219-231.

Moore, S.W., 1981, Geology of a part of the southern Monte Cristo Range, Esmeralda County, $\mathrm{Ne}$ vada: San Jose, Calif., San Jose State Unirersity, unpublished M.S. thesis, 157 p.

Nash, J.T., Siems, D.F., and Budge, Suzanne, 1985, Geochemical significance of ores and alteret rocks 
in the Gilbert district, Esmeralda County, Nevada: U.S. Geological Survey Open-File Report 85-259, $21 \mathrm{p}$.

Orris, G.J., and Kleinhampl, F.J., 1986, Preliminary mineral resource assessment of the Tonopah $1^{\circ}$ by $2^{\circ}$ quadrangle, Nevada: U.S. Geological Survey OpenFile Report 86-470, 23 p., two appendixes.

Phariss, E.I., 1974, Geology and ore deposits of the Alpine mining district, Esmeralda County, Nevada: Reno, Nev., University of Nevada, M.S. thesis, 114 p.

Robinson, P.T., and Stewart, J.H., 1984, Uppermost Oligocene and lowermost Miocene ash-flow tuffs of western Nevada: U.S. Geological Survey Bulletin $1557,53 \mathrm{p}$.

Robinson, P.T., Stewart, J.H., Moiola, R.J., and Albers, J.P., 1976, Geologic map of the Rhyolite Ridge Quadrangle, Esmeralda County, Nevada: U.S. Geological Survey Geologic Quadrangle Map GQ-1325, scale $1: 62,500$.

Sandy, John, Jr., 1965, Geology of the Lone Mountain intrusive, Esmeralda County, Nevada: New Orleans, La., Tulane University, M.S. thesis, 49 p.

Silberling, N.J., 1991, Allochthonous terranes of western Nevada, in Raines, G.L., Lisle, R.E., Schafer, R.W., and Wilkinson, W.H., eds., Geology and ore deposits of the Great Basin: Reno, Nevada, Geological Society of Nevada, p. 101-102.

Silberman, M.L., Bonham, H.F., Jr., and Osborne, D.H., 1975, New K-Ar ages of volcanic and plutonic rocks and ore deposits in western Nevada: Isochron/West, no. 13, p. 13-21.

Speed, R.C., 1977a, Excelsior Formation, west-central Nevada: stratigraphic appraisal, new divisions, and paleogeographic interpretations, in Stewart, J. H., Stevens, C.H., and Fritsche, A.E., eds., Paleozoic paleogeography of the western. United States: Society of Economic Paleontologists and Mineralogists, Pacific Section, Pacific Coast Paleogeography Symposium 1, p.325-336.

1977b, Island arc and other paleogeographic terranes of late Paleozoic age in western Great Basin, in Stewart, J. H., Stevens, C.H., and Fritsche, A.E., eds., Paleozoic paleogeography of the western United States: Society of Economic Paleontologists and Mineralogists, Pacific Section, Pacific Coast Paleogeography Symposium 1, p. 349-362.
1981, Preliminary geologic map of the Sodaville quadrangle, Mineral County, Nevada: U.S. Geological Survey Miscellaneous Field Studies Map MF1300 , scale 1:24,000.

1984, Paleozoic and Mesozoic continertal margin collison zone features: Mina to Candeliria, Nev., traverse (field trip 6), in Lintz, Joseph. Jr., ed., Western Geological Excursions: Geological Society of America, Annual Meeting, Reno, Nevada, v. 4, p. $66-80$.

Speed, R.C., and Armstrong, R.L., 1971, Fotassiumargon ages of some minerals from igneous rocks of western Nevada: Isochron/West, no. 71-1, p. 1-8.

Speed, R.C., and Cogbill, A.H., 1979, Cerozoic volcanism of the Candelaria region, Nevara: Summary: Geological Society of America Bu"letin, Part I, v. 90 , p. $143-145$.

Stewart, J.H., 1980, Geology of Nevada: Neveda Bureau of Mines and Geology Special Publicaticn 4, 136 p.

1985, East-trending dextral faults in the western Great Basin: An explanation for anoma'sus trends of pre-Cenozoic strata and Cenozoic fa'llts: Tectonics, v. 4 , no. 6 , p. 547-564.

1989, Description, stratigraphic sections and maps of middle and upper Miocene Esmeralda Formation in the Alum, Blanco Mine, and Coaldale areas, Esmeralda County, Nevada: U.S. Geological Survey Open-File Report 89-324, 27 p., map scale $1: 62,500$.

Stewart, J.H., and Diamond, D.S., 1990, Changing patterns of extensional tectonics; Overprinting of the basin of the middle and upper Miocene Esmeralda Formation in western Nevada by younger structural basins, in Wernicke, B.P., ed., Basin and Range extensional tectonics near the latitude of Las Vegas, Nevada: Geological Society of America Memoir 176, p. 447-475.

The Nevada Mineral Industry, 1987, Nevada Bureau of Mines and Geology Special Publication MI-1987, $54 \mathrm{p}$.

Whitebread, D.H., and Hardyman, R.F.; 1987, Preliminary geologic map of part of the Cedar Mountains and Royston Hills, Esmeralda and Nye Counties; $\mathrm{Ne}$ vada: U.S. Geological Survey Open-File Peport 87613 , scale 1:62,500. 
Table 1. K-Ar ages in the two 15-minute quadrangles that cover the Monte Cristo Range area, Nevada

1) Sample Number: $15158-31 \mathrm{~J}$

Location: Rock Hill 7-1/2' quadrangle, lat $38^{\circ} 13^{\prime} 24^{\prime \prime}$ N., long $117^{\circ} 54^{\prime} 10^{\prime \prime} \mathrm{W}$.

Analyst: E.H. McKee (McKee and John, 1987)

Age: $7.2 \pm 0.3 \mathrm{Ma}$

Unit: Olivine basalt flow (Tb). From middle part of 12-m-thick olivine basalt flow that caps sequence of upper Cenozoic sedimentary rocks and interlayered tuffs and lava flows. Dated rock overlaps a well defined fault that cuts the und rrlying upper Cenozoic rocks but does not significantly offset, if at all, the dated rock.

2) Sample Number: Black Balls

Location: Crow Springs 7-1/2' quadrangle, lat 38¹3'53" N., long $117^{\circ} 36^{\prime} 21^{\prime \prime} \mathrm{W}$.

Analyst: Silberman and others (1975)

Age: $7.2 \pm 0.2 \mathrm{Ma}$ on obsidian (using new constants, Dalrymple, 1979)

Unit: Black obsidian occurring as glassy round cores in perlite. Near boundary of rhyolite plug (Tr)

3) Sample Number: GLA-1

Location: Gilbert 7-1/2' quadrangle, lat $38^{\circ} 11^{\prime} 08^{\prime \prime} \mathrm{N}$., long $117^{\circ} 42^{\prime} 12^{\prime \prime} \mathrm{W}$.

Analyst: Silberman and others (1975)

Age: $8.1 \pm 0.2 \mathrm{Ma}$ on adularia and sanidine (using new constants, Dalrymple, 1979)

Unit: Quartz-adularia vein. Breccia vein consisting of dark-gray fragments of siltstone in a white matrix of medium- to finegrained quartz and fine-grained adularia and chalcedony.

4) Sample Number: GL-2

Location: Gilbert 7-1/2' quadrangle, lat $38^{\circ} 07^{\prime} 58^{\prime \prime}$ N., long $117^{\circ} 42^{\prime} 29^{\prime \prime} \mathrm{W}$.

Analyst: Silberman and others (1975)

Age: $15.5 \pm 0.5 \mathrm{Ma}$ on biotite (using new constants, Dalrymple, 1979)

14.0 $\pm 0.4 \mathrm{Ma}$ on plagioclase (using new constants, Dalrymple, 1979)

Unit: Porphyritic biotite-pyroxene andesite, Gilbert Andesite ( $\mathrm{Tg})$.

5) Sample Number: not known

Location: Devils Gate 7-1/2' quadrangle, lat $38^{\circ} 04^{\prime} 45^{\prime \prime} \mathrm{N}$ :, long $117^{\circ} 42^{\prime} 30^{\prime \prime} \mathrm{W}$.

Analyst: E.H. McKee (in Albers and Stewart, 1972)

Age: $15.5 \pm 0.6 \mathrm{Ma}$ (using new constants, Dalyrmple, 1979)

Unit: Andesite (Gilbert Andesite; unit Tg)

6) Sample Number: $1-63-4 Z$

Location: Coaldale NE 7-1/2' quadrangle, lat $38^{\circ} 08^{\prime} 17^{\prime \prime} \mathrm{N}$., long $117^{\circ} 49^{\prime} 19^{\prime \prime} \mathrm{W}$.

Analyst: E.H. McKee (McKee and John, 1987)

Age: $15.7 \pm 9.4 \mathrm{Ma}$

Unit: $10 \mathrm{~m}$ above base of upper unit (Tbju) of Blair Junction sequence. Sample from 1.5-m block of flow-banded hornblendebiotite andesite in monolithologic volcanic breccia (lahar) with angular clasts.

7) Sample Number: 1-78-9J

Location: Blair Junction 7-1/2' quadrangle, lat 3806'42" N., long $117^{\circ} 49^{\prime 2} 20^{\prime \prime} \mathrm{W}$.

Analyst: E.H. McKee (McKee and John, 1987)

Age: $16.6 \pm 0.6 \mathrm{Ma}$

Unit: Tuff unit (Tbj) of Blair Junction sequence.

Biotite-rich welded ash-flow tuff containing common fragments of andesitic lava.

8) Sample Number: CVD-2

Location: Blair Junction 7-1/2' quadrangle, lat $38^{\circ} 02.51^{\prime} \mathrm{N}$., long $117^{\circ} 50.36^{\prime} \mathrm{W}$.

Analyst: Hambrick (1984)

Age: $18.6 \pm 0.4 \mathrm{Ma}$ on sanidine

Unit: Small rhyolite plug (Tor)

9) Sample Number: 1-9-4J

Location: Gilbert 7-1/2' quadrangle, lat $38^{\circ} 11^{\prime} 05^{\prime \prime} \mathrm{N}$, long, $117^{\circ} 40^{\prime} 42^{\prime \prime} \mathrm{W}$.

Analyst: E.H. McKee (McKee and John, 1987)

Age: $19.2 \pm 0.6 \mathrm{Ma}$

Unit: Flow-banded rhyolite with sanidine phenocrysts (Tor)

10) Sample Number: $1-9-8 \mathrm{~J}$

Location: Gilbert 7-1/2' quadrangle, lat 38 $12^{\prime} 19^{\prime \prime}$ N., long $117^{\circ} 40^{\prime} 59^{\prime \prime} \mathrm{W}$.

Analyst: E.H. McKee (McKee and John, 1987)

Age: $20.0 \pm 0.5 \mathrm{Ma}$

Unit: Porphyritic rhyolite (Tpr) with phenocrysts of quartz, feldspar, and biotite. No flow banding. Probably shallow intrusive rock. 
Table 1. K-Ar ages in the two 15-minute quadrangles that cover the Monte Cristo Range area, Nevada-Continued

11) Sample Number: CVD-5

Location: Blair Junction 7-1/2' quadrangle, lat $38^{\circ} 04.35^{\prime} \mathrm{N}$., long $117^{\circ} 51.40^{\prime} \mathrm{W}$.

Analyst: Hambrick (1984)

Age: $22.2 \pm 0.5 \mathrm{Ma}$ on hornblende

Unit: Hornblende andesite (Tbji ) intrusive into lower unit (Tbjl) of Blair Junction sequence.

12) Sample Number: CVD-7

Location: Coaldale 7-1/2' quadrangle, lat $38^{\circ} 05.24^{\prime} \mathrm{N}$., long $117^{\circ} 52.54^{\prime} \mathrm{W}$.

Analyst: Hambrick (1984)

Age: $23.9 \pm 0.6 \mathrm{Ma}$ on sanidine

$24.4 \pm 0.6 \mathrm{Ma}$ on biotite

Unit: Tuff of Castle Peak (Tcp)

13) Sample Number: Redlick

Location: Coaldale 7-1/2'quadrangle, lat $38^{\circ} 09.8^{\prime} \mathrm{N}$., long $117^{\circ} 57.4^{\prime} \mathrm{W}$.

Analyst: Silberman and others (1975)

Age: $80.3 \pm 2.3 \mathrm{Ma}$ on muscovite (using new constants, Dalymple, 1979)

Unit: Altered quartz monzonite. Partially oxidized rock consisting of intergrowths of cloudy perthite, quartz, and muscovite, which appears to be primary, and minor biotite and molybdenite.

14) Sample Number: GL-15

Location: Gilbert 7-1/2' quadrangle, lat $38^{\circ} 10^{\prime} 39^{\prime \prime}$ N., long $117^{\circ} 42^{\prime} 26^{\prime \prime} \mathrm{W}$.

Analyst: Silberman and others (1975)

Age: $198 \pm 4$ Ma on sericite (using new constants, Dalyrmple, 1979)

Unit: Altered quartz monzonite porphyry. Quartz-sericite alteration of porphyritic rock with quartz and feldspar phenocrysts. Biotite and feldspar are altered to muscovite. Stringers and veins of quartz are present. The rock crnsists of quartz, sericite, and minor limonite after pyrite.

15) Sample Number: YU-NibuU

Location: Gilbert $7-1 / 2^{\prime}$ quadrangle, lat $38^{\circ} 15^{\prime} \mathrm{N}$. , long $117^{\circ} 34^{\prime} \mathrm{W}$.

Analyst: Speed and Armstrong (1971)

Age: $207 \pm 3 \mathrm{Ma}$ on homblende (using new constants, Dalymple, 1979)

Unit: Porphyritic granodiorite composed of plagioclase, quartz, 10-15 percent homblende, and highly variable abundances of coarse potassium-feldspar phenocrysts. 
Table 2. Fossils in the two 15 -minute quadrangles that cover the Monte Cristo Range area, Nevada.

[CAl: Conodont Alteration Index (Epstein and others, 1977)]

\section{GRAPTOLTES}

(identified by Claire Carter)

1) Sample Number: $11542-29 \mathrm{~J}$,

Location: Devils Gate 7-1/2' quadrangle, lat $38^{\circ} 04^{\prime} 58^{\prime \prime} \mathrm{N}$., long $117^{\circ} 39^{\prime} 05^{\prime \prime} \mathrm{W}$.

Fauna: Cryptograptus schaeferi Lapworth

Glossograptus cf. G. ciliatusEmmons

Climacograptus sp.

Dicellograptus? (fragment)

Glyptograptus? sp. aff. G. teretiusculus (Hisinger)

Age: Approximately zone of Glyptograptus teretiusculus, Middle Ordovician

Rock unit: Siliceous and volcanic rocks (DE sv)

\section{RADIOLARIANS}

(identified by B. L. Murchey and D.L. Jones)

2) Sample number: 11542-25J (MR number 3845)

Location: Blair Junction 7-1/2' quadrangle, lat $38^{\circ} 06^{\prime} 12^{\prime \prime}$ N., long $117^{\circ} 46^{\prime} 05^{\prime \prime} \mathrm{W}$.

Fauna: Abundant spheroidal radiolarians, but less than 10 percent have any structure preserved. A few spheroidal spumellarians have 4 to 6 tripartite-bladed spines (medium thickness, straight). More than 10 percent sponge spic "les, mostly monaxon but hexactine forms are common.

Age: Late Devonian to Permian

Rock unit: Siliceous and volcanic rocks (DEsv)

3) Sample number: 11540-30J (MR number 3846)

Location: Blair Junction 7-1/2' quadrangle, lat $38^{\circ} 06^{\prime} 65^{\prime \prime} \mathrm{N}$., long $117^{\circ} 47^{\prime} 14^{\prime \prime} \mathrm{W}$.

Fauna: Abundant poorly preserved spheroidal radiolarians; less than 1 percent have any structure preserved. A few attached spine fragments seem to be circular in cross section but one may be tripartite bladed. 1-3 percent sponge spicules.

Age: Paleozoic

Rock unit: Siliceous and volcanic rocks (D€sv)

\section{CORALS}

(identified by W.J. Sando)

4) Sample number: 76FP-62F (USGS 28065-PC)

Location: Coaldale NE 7-1/2' quadrangle, lat $38^{\circ} 09^{\prime} 59^{\prime \prime} \mathrm{N}$., long $117^{\circ} 47^{\prime} 48^{\prime \prime} \mathrm{W}$.

Collected by: F.G. Poole.

Fauna: Faberophyllum? sp. The corals are fragmentary and silicified; poor preservation makes generic identification uncertain. They appear to be the same genus as in 76-FP-91F and the age is probably the same.

Rock unit: carbonate rocks (Mc)

5) Sample number: 76FP-91F (USGS 28066-PC)

Location: Coaldale NE 7-1/2' quadrangle, lat $38^{\circ} 10^{\prime} 02^{\prime \prime} \mathrm{N}$., long $117^{\circ} 47^{\prime} 53^{\prime \prime} \mathrm{W}$.

Collected by: F.G. Poole

Fauna: Faberophyllum sp.

Age: Coral Zone IV, late Meramecian (Late Mississippian)

Rock unit: carbonate rocks (Mc)

6) Sample number: 76FP-179F (USGS 28067-PC)

Location: Coaldale NE 7-1/2' quadrangle, lat 3806'30" N., long $117^{\circ} 50^{\prime} 47^{\prime \prime} \mathrm{W}$.

Collected by: F.G. Poole.

Fauna: Syringopora sp.

Age: Probably Mississippian

Rock unit: carbonate rocks (Mc) 
7) Sample number: 15075-8JB (USGS 29335-PC)

Location: Coaldale NE 7-1/2' quadrangle, lat 38 $09^{\prime} 58^{\prime \prime}$ N., long $117^{\circ} 47^{\prime} 47^{\prime \prime} \mathrm{W}$.

Fauna: Hindeodus penescitulus (Rexroad and Collinson)

Hindeodus scitulus (Hinde)

Age: Late Mississippian (late Meramecian)

Rock unit: carbonate rocks (Mc)

CAI: 5.5

8) Sample number: 15075-19J (USGS 29336-PC)

Location: Coaldale NE 7-1/2' quadrangle, lat $38^{\circ} 08^{\prime} 12^{\prime \prime}$ N., long $117^{\circ} 51^{\prime} 34^{\prime \prime} \mathrm{W}$.

Fauna: Idiognathodus sp.

Idiognathoides sinuatus Harris and Hollingsworth

Neogondolella $\mathrm{n}$. sp.

Age: Atokan (Middle Pennsylvanian)

CAI: 3.0

Rock unit: Havallah sequence $(\mathrm{Ph})$,

9) Sample number: 15075-27J (USGS 29337-PC)

Location: Coaldale NE 7-1/2' quadrangle, lat 3807'59" N., long $117^{\circ} 51^{\prime} 05^{\prime \prime} \mathrm{W}$.

Fauna: Cauusgnathus sp.

Hindeodus scitulus (Hinde), an undetermined abraded gnathodid or polygnathid fragment

Age: Late Mississippian (late Meramecian to early Chesterian)

CAI: 5.5

Rock unit: carbonate rocks $(\mathrm{Mc})$

10) Sample number: 15077-60JA (USGS 29340-PC)

Location: Gilbert 7-1/2' quadrangle, lat $38^{\circ} 09^{\prime} 06^{\prime \prime} \mathrm{N}$., long $117^{\circ} 42^{\prime} 32^{\prime \prime} \mathrm{W}$.

Fauna: Neogondolella n. sp.

Age: Atokan (Middle Pennsylvanian)

CAI: $5.5-6.0$ (these 2 corroded fragments are not easily determined)

Rock unit: Havallah sequence (Ph)

11) Sample number: 15077-60JB (USGS 29338-PC)

Location: Gilbert 7-1/2' quadrangle, lat $38^{\circ} 09^{\prime} 06^{\prime \prime} \mathrm{N}$., long $117^{\circ} 42^{\prime} 32^{\prime \prime} \mathrm{W}$.

Fauna: Hindeodus sp.

Idiognathodus delicatus Gunnell

Idiognathoides sinuatus Harris and Hollingsworth

Neogondolella $\mathrm{n}$. sp.

This fauna is similar to that of USGS 29336-PC.

Age: Atokan (Middle Pennsylvanian)

CAI: 5.5

Rock unit: Havallah sequence (Ph)

12) Sample number: $15075-66 \mathrm{JA}$

Location: Coaldale NE 7-1/2' quadrangle, lat 38 $08^{\prime} 40^{\prime \prime} \mathrm{N}$., long $117^{\circ} 47^{\prime} 28^{\prime \prime} \mathrm{W}$.

Fauna: Undetermined fragment of gnathodid of possible Mississippian age

CAI: 5.5

Rock unit: carbonate rocks (Mc)

13) Sample number: 15077-69JA (USGS 2941-PC)

Location: Gilbert 7-1/2' quadrangle, lat $38^{\circ} 08^{\prime} 43^{\prime \prime} \mathrm{N}$., long $117^{\circ} 42^{\prime} 37^{\prime \prime} \mathrm{W}$.

Fauna: Adetognathus unicornis (Rexroad and Burton). undetermined large $(+5 \mathrm{~mm})$ ramiform element

Age: Late Chesterian (Late Mississippian)

CAI: 5.5

Rock unit: carbonate rocks (Mc)

14) Sample number: 15077-69JB (USGS 29339-PC)

Location: Gilbert 7-1/2' quadrangle, lat $38^{\circ} 08^{\prime} 43^{\prime \prime} \mathrm{N}$., long $117^{\circ} 42^{\prime} 37^{\prime \prime} \mathrm{W}$.

Fauna: Hindeodus minutus (Ellison) a cavusgnathid or adetognathid fragment.

Age: Late Chesterian (Late Mississippian). This age is largely based on the associated sample USGS 29341-PC wh"ch contains

CAI: 5.5 Adetognathus unicornis.

Rock unit: carbonate rocks (Mc) 
Table 2. Fossils in the two 15-minute quadrangles that cover the Monte Cristo Range area, Nevada.

[CAI: Conodont Alteration Index (Epstein and others, 1977)]-Continued

\section{DIATOMS}

(identified by J. Platt Bradbury)

15) Sample number: $11542-40 \mathrm{~J}$ (Diatom locality number 22 VII 83-1)

Location: Devil's Gate 7-1/2' quadrangle, lat 3805'48" N., long $117^{\circ} 40^{\prime} 25^{\prime \prime} \mathrm{W}$.

Flora: This sample is dominated by Melosira "praedistans". The form has a very narrow sulcus without collar marking? and a dense, regularly punctate disk. Forms similar to this type are common in Miocene diatomites of the western Ur"ted States, but closely comparable to living forms. Without detailed morphological studies little can be said about its age significance.

Rock unit: sedimentary rocks of McLeans (Tm)

16) Sample number: $11542-61 \mathrm{~J}$ (Diatom locality number $22 \mathrm{~V} 11$ 83-2)

Location: Devil's Gate 7-1/2' quadrangle, lat 3804'27" N., long $117^{\circ} 41^{\prime} 40^{\prime \prime} \mathrm{W}$.

Flora: This sample is characterized by Melosira praeislandica and an apparent variant of this species that closely resenrbles $M$. canadensis. Fragilaria construens v. venter, F. pinnata, and other Fragilaria species are also present. The Melosira praeislandica type is characterized by a regular marginal radial segmentation on the value face. There are also vary rare occurrences of discoid centric diatoms such as Actinocyclus sp. and Stephanodiscus Thalassiosira sp.

Rock unit: Esmeralda Formation (Te)

17) Sample number: $11540-5 \mathrm{~J}$ (Diatom locality number $12 \times 83-2$ )

Location: Blair Junction 7-1/2' quadrangle, lat $38^{\circ} 6^{\prime} 18^{\prime \prime} \mathrm{N}$., long $117^{\circ} 48^{\prime} 47^{\prime \prime} \mathrm{W}$.

Flora: Fragilaria construens v. venter abundant Fragilaria pinnata abundant

Melosira teres common

Tetracyclus ellipticus very rare

Pinnularia sp.

Cymbella sp. cf. C. cistula

Age: The diatoms of this sample are not generally age diagnostic. Tetracyclus elipticus is often characteristic of Miorene deposits of this presumed age range. The dominance of Fragilaria species suggests shallow, fresh water.

Rock unit: sedimentary rocks of McLeans (Tm). Outcrop too small to show on map

18) Sample number: $11542-6 \mathrm{~J}$ (Diatom locality number $12 \times 83-5$ )

Location: Devil's Gate 7-1/2' quadrangle, lat 38 $5^{\prime} 13^{\prime \prime}$ N., long $117^{\circ} 44^{\prime} 57^{\prime \prime} \mathrm{W}$.

Flora: This sample is dominated by Melosira sp. cf. M. islandica. This species appears as a very thin and sometimes rurved form, and has distinctive minute collar coastae in pervalvar view. Other species that occur rarely in this sample are Melosira teres, Melosira distans?, tiny Melosira sp., Fragilaria sp. cf. F. pinnata and F. construens v. venter. One fragment of Actinocyclus sp. was seen.

Age: Melosira sp. cf. M. islandica is probably an extinct species, but resembles many Melosiria species from Miocen? deposits of the western United States.

Rock unit: sedimentary rocks of McLeans (Tm). Outcrop is too small to show on map

19) Sample number: $15075-2 \mathrm{~J}$ (Diatom locality number $12 \times 83-6$ )

Location: Coaldale NE 7-1/2' quadrangle, lat 38 $09^{\prime} 52^{\prime \prime} \mathrm{N}$., long $117^{\circ} 52^{\prime} 15^{\prime \prime} \mathrm{W}$.

Flora: This sample is characterized by two types of Melosira, M. granulata var jonensis, an extant tropical specie: and Melosira sp. cf. M. candadensis.

-Age: Melosira sp. cf. M. candadensis is moderately common in Miocene deposits of Oregon and Washington.

Rock unit: sedimentary rocks of McLeans (Tm)

20) Sample number: 15075-17J (Diatom locality number $12 \times 83-7$ )

Location: Coaldale NE 7-1/2' quadrangle, lat 38 $09^{\prime} 10^{\prime \prime}$., long $117^{\circ} 51^{\prime} 38^{\prime \prime} \mathrm{W}$.

Flora: The sample is characterized by a thin and curved form of Melosira islandica or something that resembles that ax sn. It is similar to the Melosira species in sample 11542-6J, and it would not surprise me if these two outcrops contain correlative strata. Other diatoms in the sample are $M$. praeislandica? M. distans, Fragilaria sp., and Tetracyclus ellipticus which is very rare.

Rock unit: sedimentary rocks of McLeans (Tm) 
Table 2. Fossils in the two 15 -minute quadrangles that cover the Monte Cristo Range area, Nevada. [CAI: Conodont Alteration Index (Epstein and others, 1977)]-Continued

\section{MOLUUSKS}

(dentified by John H. Hanley)

21) Sample number: $15077-104 \mathrm{~J}$ (Cenozoic mollusk locality D1474NM)

Location: Gilbert 7-1/2' quadrangle, lat $38^{\circ} 11^{\prime} 22^{\prime \prime} \mathrm{N}$., long $117^{\circ} 42^{\prime} 03^{\prime \prime} \mathrm{W}$.

Fauna: Interpretation of this sample is limited by somewhat poor preservation and by poor separation of matrix from the margins of the specimens. As a result, identifications are conservative.

It appears that two discrete beds were sampled. Mollusks occur in a dark-gray, mildy calcareous (dolomitic?'; mudstone. A second light-yellowish-brown rock type appears to be conglomeratic with small, punky white, (volcanic?) clast -

The latter rock type contains fish vertebrae, but no mollusks. The mollusk-bearing matrix has been retainec' in our collections. A single bivalve (clam) specimen is preserved as an internal mold. Size and general form of the mcld are similar to that of the Genus Pisidium, a small freshwater bivalve of the Family Sphaeriidae commonly called fin ternail clams.

A single, incomplete, immature specimen is questionably assigned to the Genus Goniobasis. Sculpture on this specimen is similar to that of other Miocene and Pliocene species of Goniobasis reported from the western United States, for example Goniobasis taylori (Gabb).

Age: Gastropods of the Genus Vorticifex indicate the sample is Miocene to Pliocene in age. Review of the literature at hand suggests that Vorticifex occurs in rocks of late Miocene and early Pliocene age, and that the genus occurs in Nivada, Idaho, and Utah.

Rock unit: undivided sedimentary rocks (Tsu)

22) Sample number: $11542-52 J$ (Cenozoic mollusk locality D1475NM)

Location: Devils Gate 7-1/2' quadrangle, lat $38^{\circ} 6^{\prime} 22^{\prime \prime}$ N., long $117^{\circ} 38^{\prime} 47^{\prime \prime}$. W.

Fauna: Bivalves

Bivalvia: Genus and species indeterminate

Gastropods -

Valvata? sp. indet.

Viviparus sp. indet.

Biomphalaria sp. indet.

Planorbidae: Genus and species indet.

Ostracodes

Fish vertebrae

Interpretation of this fauna is limited by somewhat poor preservation. The mollusks clearly inhabited a frest water environment. Absence of unionid bivalves and generic composition of the gastropods indicate a shallow', quiet-

Age: undetermined water lake or pond environment.

Rock unit: sedimentary rocks of McLeans $(\mathrm{Tm})$ 


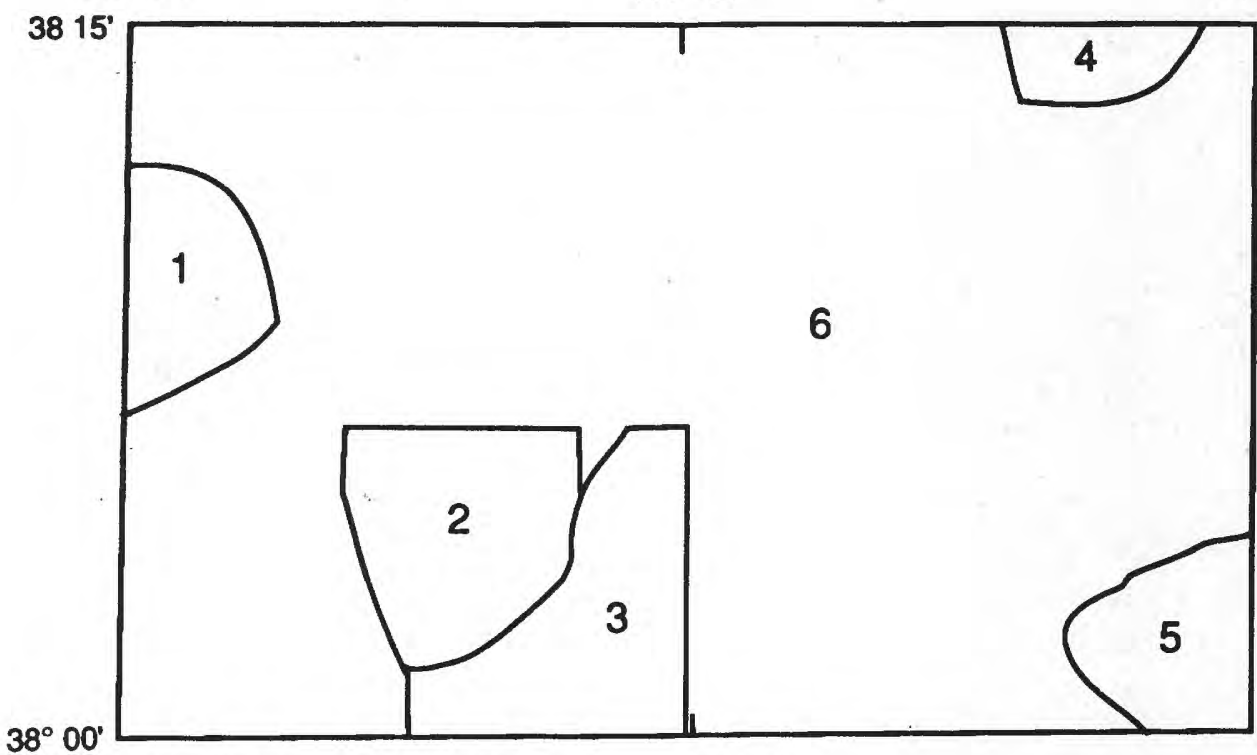

1 R.C. Speed, written commun., 1985

2 Hambrick (1984)

3 Moore (1981)

4 D.H. Whitebread, written commun., 1986

5 Phariss (1974) and Maldonado (1984). Foliation in Lone Mountain pluton from D.A. John, written commun., 1986

6 J.H. Stewart, P.C. Kelleher, and E.A. Zorich, 1982 to 1985

Figure 1. Index to sources of mapping in Monte Cristo Range area, Nevada

\begin{tabular}{|c|c|c|c|}
\hline $\begin{array}{c}\text { Rock } \\
\text { Hill }\end{array}$ & $\begin{array}{c}\text { Coaldale } \\
\text { NE }\end{array}$ & Gilbert & $\begin{array}{c}\text { Crow } \\
\text { Springs }\end{array}$ \\
\hline & & Blair \\
& Junction & Devils & Gate \\
Coaldale & & & Gilbert \\
& & & SE \\
& & & \\
\hline
\end{tabular}

Figure 2. Index to U.S. Geological Survey $71 / 2$ ' quadrangles in Monte Cristo Range area, Nevada 


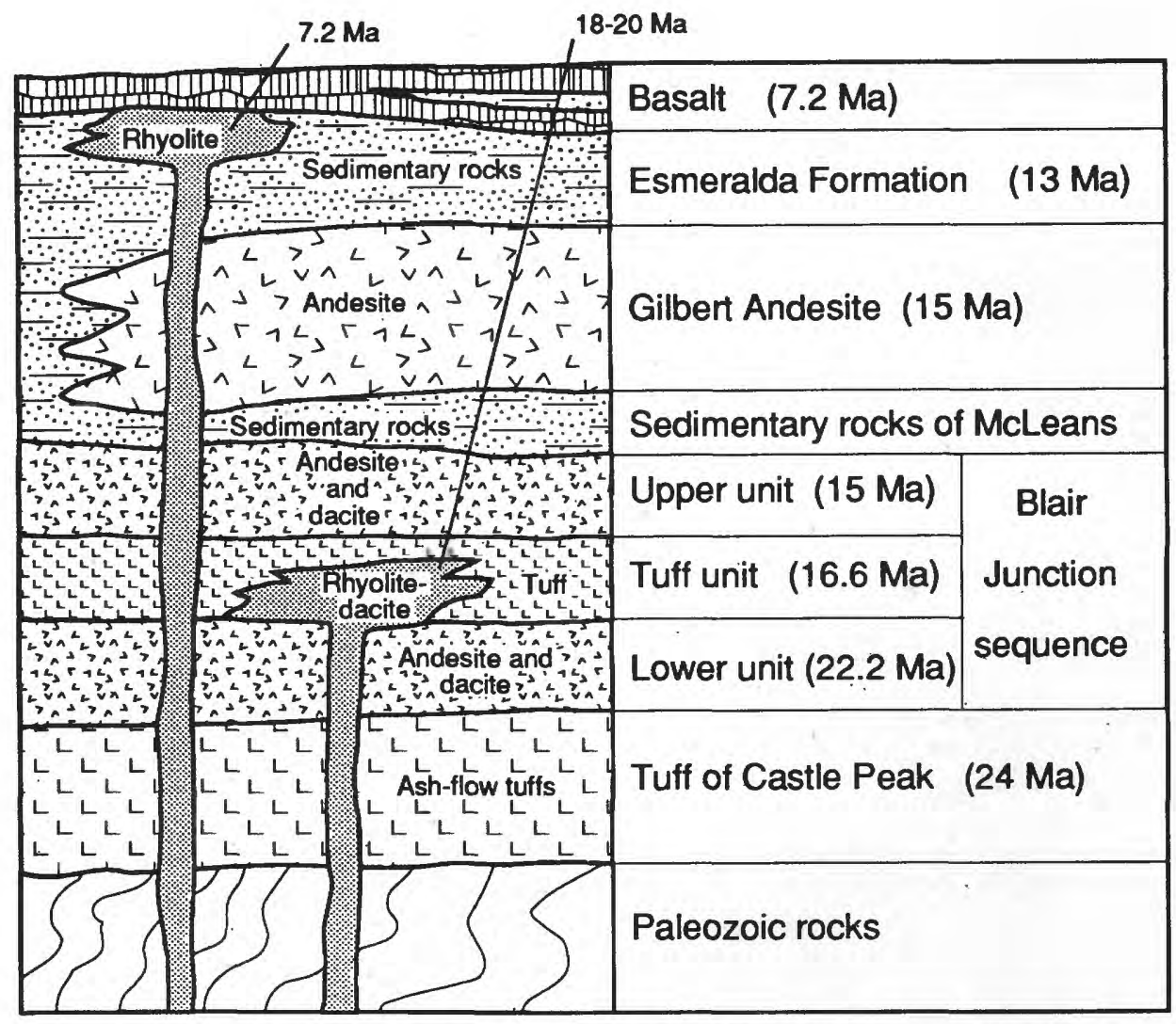

Figure 3. Relations of major units in Monte Cristo Range area, Nevada

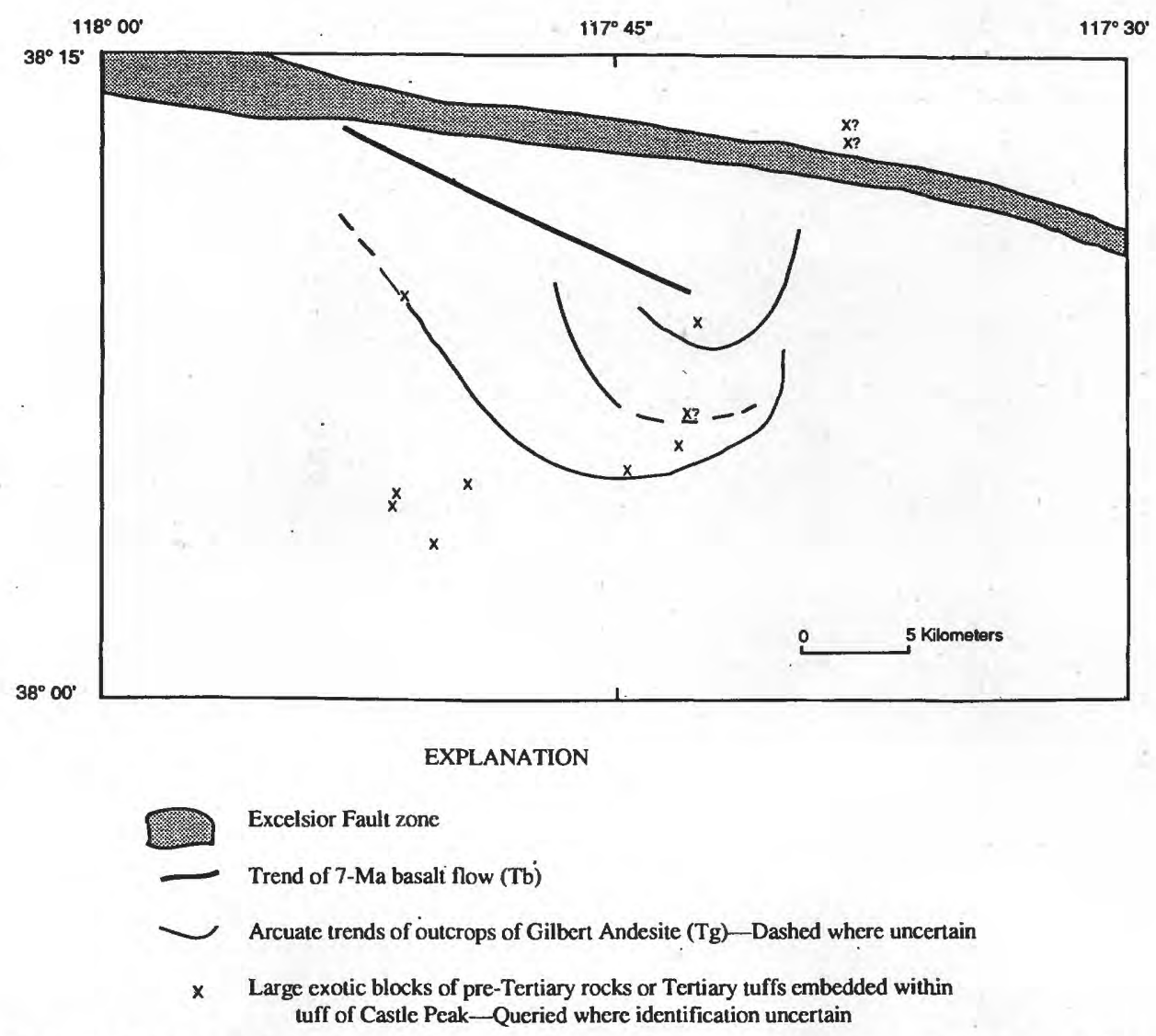

Figure 4. Structural trends and location of exotic blocks in Monte Cristo Range area, Nevada 


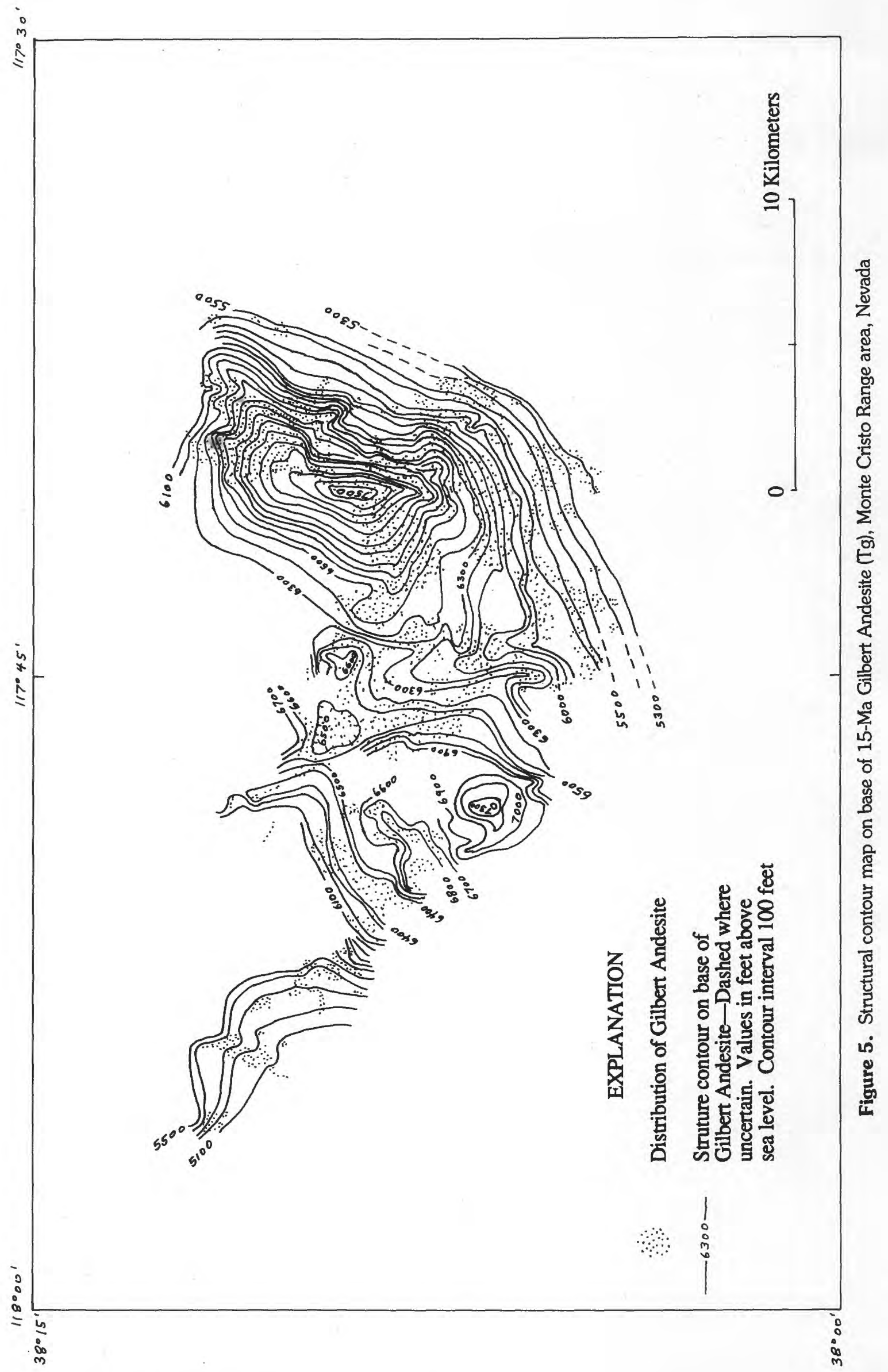

*U.S. G.P.0.: 1994-301-077:80104 
